Article

\title{
Public Administration and the Study of Political Order: Towards a Framework for Analysis
}

\author{
Jarle Trondal ${ }^{1,2}$ \\ ${ }^{1}$ Department of Political Science and Management, University of Agder, 4604 Kristiansand, Norway; \\ E-Mail: jarle.trondal@uia.no \\ ${ }^{2}$ ARENA Centre for European Studies, University of Oslo, 0318 Oslo, Norway; E-Mail: jarle.trondal@arena.uio.no
}

Submitted: 16 May 2020 | Accepted: 25 August 2020 | Published: 3 November 2020

\begin{abstract}
The contribution of this study is two-fold: First, it outlines a conceptual framework on political order; and secondly, it offers empirical illustrations on the case of Nordic cooperation. Taken together, the article makes a plea for public administration scholarship in the study of political order. Political order consists of a relatively stable arrangement of institutions that are fairly formalized and institutionalized. A common political order, moreover, entails that relevant institutions: (i) are fairly independent of pre-existing institutions; (ii) are relatively integrated and internally cohesive; and (iii) are reasonably able to influence governance processes within other institutions. The article empirically suggests that Nordic-level institutions are less likely to act relatively integrated and independently of member-state governments as well as being able to wield significant influence on public governance processes within member-state institutions.
\end{abstract}

\section{Keywords}

multilevel administration; multilevel governance; Nordic cooperation; organizational approach; political order; public administration

Issue

This article is part of the issue "Rediscovering Nordic Cooperation" edited by Anne Elizabeth Stie (University of Agder, Norway) and Jarle Trondal (University of Agder, Norway/University of Oslo, Norway).

(C) 2020 by the author; licensee Cogitatio (Lisbon, Portugal). This article is licensed under a Creative Commons Attribution 4.0 International License (CC BY).

\section{Introduction}

Turbulence within and around public affairs calls for understanding the conditions for resilient and sustained political order (Ansell, Trondal, \& Ogard, 2016; Fukuyama, 2016; Olsen, 2007; Tamuz \& Lewis, 2008). The challenge of understanding social and political order is enduring in the social sciences (Elster, 2007; Waldo, 1992) with continuous disputes over "the legitimate role of democratic politics in society" and "forms of political association" (Olsen, 2016, pp. 1-5). So-called failed states, such as Syria fairly recently, accentuate the concern for stabile political order. Periods of crisis, like the Covid-19 crisis, have also highlighted the importance of efficient, resilient and legitimate political order. During historical periods of stability, by contrast, the significance of political order is often taken for granted. During periods of political deterioration, organized arrangements become subject to debate and requests for reforms (Fukuyama, 2013; Pepinsky \& Walter, 2019; Trondal, 2010). With an ambition to rediscover the study of Nordic cooperation as well as to advance studies of political order, this study offers ways to theoretically conceptualize politicoadministrative order in the Nordic region. The contribution is two-fold: First, it outlines a conceptual framework that highlights the administrative dimension of political order; secondly, merely to illustrate the framework, the article offers empirical illustrations of emergent political order in the European Union (EU) as well as Nordic cooperation.

Unveiling political order involves studying why such orders emerge and disappear (e.g., Bartolini, 2005; Fukuyama, 2013; March \& Olsen, 1995; Padgett \& Powell, 2012), their consequences-especially how they influence policy outcomes (e.g., Olsen, 2007; Orren \& Skowronek, 2004)-and how political order may be the- 
oretically conceptualized (e.g., Stinchcombe, 1987). This article is particularly interested in the latter. Perhaps unsurprisingly for institutional building-sites such as the Nordic cooperative arrangements, the institutional soul searching is intense. Studies of unsettled and transitional political orders are, however, much less prominent. Since the classics in administrative sciences (e.g., Gulick, 1937) and up to recent studies of public administration (Emery \& Giauque, 2014; Olsen, 2016) the largest focus has been on the study of settled political orders. One notable exception has been a vibrant literature on the study of international public administrations (IPAs; e.g., Barnett \& Finnemore, 2004; Bauer, Beyerlein, Ege, Knill, \& Trondal, 2019; Bauer \& Trondal, 2015; Trondal, 2016; Trondal \& Bauer, 2017; Trondal, Marcussen, Larsson, \& Veggeland, 2010). International bureaucracies constitute a distinct and increasingly important feature of both global governance studies and public administration scholarship. The IPA literature has advanced these types of studies by offering a 'public administration' approach. This entails that the study of international governmental organizations has been somehow 'normalized,' i.e., that a public administration turn comes to characterize international governmental organizations studies (Trondal, 2007). Studies have shown that IPAs profoundly influence global governance (Biermann \& Siebenhüner, 2009), transform power distributions across levels of government (Egeberg \& Trondal, 2009), and change the conduct of domestic public sector governance (Keohane, Macedo, \& Moravcsik, 2009). Moreover, IPAs are called upon to cope with ever more wicked and unruly public problems. Turbulence in world politics is partly caused by turbulent politico-administrative systems, partly by turbulent environments, and partly by how organizations and their environments poorly match-thus creating turbulence of scale. IPAs may be seen as one coping mechanism in an ever more turbulent global scene (Ansell et al., 2016).

Crisis and disintegration have faced 'grand-theories' of European integration such as neo-functionalism and intergovernmentalism with conceptual and explanatory difficulties, while mid-range theories such as institutionalisms have fared comparatively better (Riddervold, Trondal, \& Newsome, 2020). Yet, most discussions of theoretical rehabilitation in the literature have focused on the role of grand-theories, leaving mid-range accounts less discussed. One reason might be that big theoretical ideas may explain general trends more adequately than particularities of cases (e.g., Boin \& Lodge, 2016). This article aims to fill the void of mid-range theorizing by applying a mid-range institutionalist approach to conceptuality examine political order.

A common political order arguably consists of a relatively stable arrangement of institutions that are fairly formalized and institutionalized. A common political order arguably requires that relevant institutions are: (i) fairly independent of pre-existing institutions; (ii) relatively integrated and internally cohesive; and (iii) rea- sonably able to influence governance processes within other institutions. In sum, a political order is characterized as a fairly independent, integrated and influential set of institutions that allocate "authority, power, information, responsibility, and accountability" (Olsen, 2016, p. 3). However, one caveat needs to be taken into account: An 'order' does not suggest institutions that are perfectly integrated, coordinated and impeccably independent. They are often imperfectly so (Trondal \& Bauer, 2017).

The research question of this study is to what extent Nordic cooperation rises into some kind of 'common' order. To illustrate: In a Nordic context a common order lets us infer that Nordic institutions are able to act relatively independently of member-state governments, be fairly integrated internally (within and among the Nordic institutions), and able to exert influence on the policy processes of member-state institutions-thus ultimately challenging the politico-administrative autonomy of the constituent states. This article, however, suggests that Nordic-level institutions (notably the Nordic Council of Ministers and its Secretariat) in practice are less likely to act relatively integrated and independently of member-state governments and less likely to wield significant influence on public governance processes within the member-state institutions. In the case of Nordic cooperation, most primary administrative capacities are located within national ministries and agencies, and relatively few at the 'Nordic level'. Member-state administrations are subsequently likely to primarily influence policy agendas and policy implementation.

The article is presented as follows: The next section outlines a research agenda by outlining a public administration framework; the subsequent sections suggest conceptual dimensions that might be used for empirical study.

\section{A Research Agenda}

Studies of state-building demonstrate that the emergence of political orders involves balancing acts between creating central politico-administrative capacities and institutions safeguarding local independence (Rokkan, 1999). Recent literature moreover demonstrates that the rise of politico-administrative systems at EU-level transforms policy processes at national level. For example, studies show that the European Commission profoundly biases power distributions across levels of government and circumvents domestic democratic governance processes (e.g., Egeberg \& Trondal, 2009; Trondal, 2016).

We have seen three subsequent waves of studies on political order, and this article serves as part of the third wave. Briefly sketched, the first wave largely saw domestic political orders as sealed systems of governance in which phenomena external to the nation-state were conceptually treated as exogenous epiphenomena (Wilson, 1989). Studies of public administration was thus largely circumscribed to the study of domestic govern- 
ing systems (e.g., Christensen \& Lægreid, 2007). A second wave of studies directed attention to how international institutions - such as IPAs-contributed to the transformation of national political order. These studies illuminated processes of transformation from an inherent Westphalian towards a post-Westphalian order characterized by a restructuring of political authority (e.g., Bartolini, 2005; Egeberg, 2006) towards institutionalized multilevel governance (MLG; Ansell \& Di Palma, 2004; Hooghe \& Marks, 2001). This second surge of literature both included the research programme on MLG by Gary Marks and Liesbet Hooghe as well the first wave of literature on multilevel administration (MLA I, see Section 4). From the 1960s, studies of administrative integration emerged focusing on the integration of domestic and international administrative bodies. Studies of administrative integration argued that the domesticinternational distinction was conceptually and empirically fuzzy (Rosenau, 1966). The "descriptions of the [EU] Community as 'above,' 'alongside' or 'outside' the member states were seen as oversimplifications" (Pag, 1987 , p. 446), stressing 'bureaucratic inter-penetration' between member-state and EU administrative bodies (Cassese, 1987; Rosenau, 1966). More recently, the interdependencies of political orders has perhaps been most successfully captured by the MLG approach (Hooghe \& Marks, 2001). The European political order is thus seen as a polymorphic system that integrates governance levels into a complex marble cake consisting of a patchwork of separate but interconnected political institutions at different levels of authority (e.g., Bulmer, 2008, p. 173).

This article subscribes to a third wave of study by highlighting the administrative basis for political order and the organizational dimension of public governance (MLA II, see Section 4). This field of study has been particularly interested in understanding European administrative institution-building (Egeberg, 2006; Rittberger \& Wonka, 2011) and more recently the organizational foundation of a multilevel European administrative system (Curtin \& Egeberg, 2008; Egeberg, 2010; Egeberg \& Trondal, 2009). The European administrative system has subsequently been pictured as a "multilevel and nested network administration, where administrative bodies at different levels of government are linked together in the performance of tasks" (Hofmann \& Turk, 2006, p. 583). In short, this third wave of literature has been seen as representing a 'public administration turn' in the study of political order (Trondal, 2007).

\section{Public Administration and the Study of Political Order}

In an effort to conceptualize Nordic cooperation in particular and to capture basic aspects of political order in general (Painter \& Peters, 2010, p. 6; Waldo, 1992, p. 37), this article suggests how the study of public administration may be helpful to conceptually frame political order. One enduring challenge in conceptualizing political order is to establish theoretically powerful and empirically helpful categories that capture essential and enduring characteristics (e.g., Fukuyama, 2016, p. 222). Our starting assumption is that adequate analytical categories should both offer more empirical variation between than within categories as well as be generalizable across time and space. Examples of less meaningful categories are those treating institutions as sui generis. Such concepts are not generalizable across time and space and easily prevent the accumulation of general knowledge. One recent example is new intergovernmentalism picturing EU agencies as "de novo bodies" (Bickerton, 2012).

Our approach puts the administrative dimension of political order conceptually center stage. There are at least two key reasons for doing so. The first is that administrations represent the action capacities for political orders. Without administrative institutions, public policies will not be initiated, drafted, nor implemented (Fukuyama, 2013). Moreover, the well-being of citizens is shown to be nurtured by societies administered by 'impartial' public bureaucracies (Rothstein, 2012). So, administrative capacities are central for making 'good' and 'living' political orders (March \& Olsen, 1989). Secondly, the administrative dimension is by and large neglected in studies of political order (e.g., Rokkan, 1999). In EU studies the administrative dimension has been largely neglected by leading theoretical approaches, such as social constructivism (Checkel, 2005) and intergovernmentalism (Moravcsik, 1998). In effect, advancing a public administration approach to the study of political order, this article supports a thread of thought from neo-functionalist literature which argued that bureaucratic integration of administrative elites was vital for European integration (Haas, 1958, p. 16; Niemann, 2006, p. 280). Moreover, despite focusing on the administrative dimensions of political order, the role of public administration is not analyzed in isolation-as an "intellectual wasteland" (Bobrow, Eulau, Landau, Jones, \& Axelrod, 1977, p. 421)-but as requisite capacities that mobilize 'bias' in the making of public policy (Schattschneider, 1975). A public administration approach to political order formation is thus also a theory of political organization (Olsen, 2016).

Notwithstanding developments in the study of the EU administrative system (Bauer \& Trondal, 2015; Trondal \& Bauer, 2017), contemporary public administration scholarship faces one major challenge. Public administration literature has devoted limited attention to broader discussions on how administrations affect the growth and decline of political order: This literature has for instance not payed much attention to how changing structuring of the state-e.g., agencification and networking of agencies-coincide with forms of multilevel administrative governance (Danielsen \& Yesilkagit, 2014; Egeberg, 2006; Fukuyama, 2013; Raadschelders, 2011; Trondal, 2014). It has not sufficiently studied how organizing public policy at one level of governance may influence ways of making public policy across levels of gover- 
nance (Egeberg \& Trondal, 2016). The next section suggests how administrative science may provide a conceptual toolkit to the study of political order.

\section{Conceptual Dimensions of Multilevel Administration}

The EU has served as an important research laboratory for understanding political order (e.g., Olsen, 2007). To conceptualize Nordic cooperation, this article builds conceptually on this scholarly laboratory. One main thread in this literature has been on the multilevel nature of the EU polity (Marks, 1993; Piattoni, 2010). According to Trondal and Bauer (2017), a 'level' refers to the distinct and independent institutions, rules, procedures and personnel. A multilevel order thus encompasses distinct and independent platforms that connect these elements at national level with parallel elements at the level above. This platform of elements consists of a puzzling mix of institutional autonomy and institutional interdependence across levels of governance. It contains institutions that act relatively independently from domestic governments as well as enjoy institutional interdependencies or ties between the same institutions (see March, 1999). Recognized by the MLG literature (Hooghe \& Marks, 2001), studying this mix of institutional autonomy and interdependencies is vital in order to adequately capture the multilevel character of Nordic cooperation.

Moreover, despite contemporary literature having seen European multilevel order as centered on its administrative dimension (Trondal \& Peters, 2013), we have seen two waves of MLA literatures (hereby termed MLA I and MLA II). This study draws attention to the second wave of MLA II literature:

- MLA I: The first surge of MLA studies was particularly interested in the convergence of administrative systems and the convergences of public policies between EU member-states (Olsen, 2007). MLA was thus measured by its outcome-that is if administrative forms, practices and ways of doing things became more similar across the memberstates. This field of study emerged from the literature of comparative government and comparative public administration, examining the roots of common administrative systems (Knill, 2001; Meyer-Sahling \& Yesilkagit, 2011) and management practices (Christensen \& Lægreid, 2011). 'MLA' was conceived of as the "convergence on a common European model" (Olsen, 2003, p. 506). In this thematic issue, Lægreid and Rykkja (2020) reflect this approach by their study of administrative cooperation among Nordic ministries and agencies, focusing on the emergence of convergent administrative policies among Nordic states.

- MLA II: A more recent line of research conceives of MLA as featuring novel institutional constellations and configurations. This line of research is in- terested in examining and understanding patterns or processes of integration of public administration institutions-not their outcomes (e.g., Benz, 2015). Such studies have been preoccupied with both understanding processes of European administrative capacity-building (e.g., Rittberger \& Wonka, 2011) and processes of multilevel administrative governance of ministerial departments and public agencies (Curtin \& Egeberg, 2008; Egeberg, 2010; Egeberg \& Trondal, 2009).

Following MLA II, three analytical dimensions have been suggested for analysis in this literature: institutional independence, influence, and integration (Trondal \& Bauer, 2017). A multilevel administrative system is thus characterized by the emergence of institutions that are relatively coherent, independent, and able to influence other institutions. Each of these items is shortly discussed in the following sub-sections.

\subsection{Independence}

Political order formation involves continuous tensions between administrative dependence and independence within and between administrative systems (Trondal, 2017). Political order involves institutionalizing relatively independent administrative capacities; that is, the permanent governing institutions that operate relatively independently of pre-existing political institutions (Matthews, 2012). Huntington (1968) saw autonomy as a necessary requirement of state-formation. Saint-Simon (1964, pp. 35-38) also argued that one necessary factor in building political order is the making of administrative systems that consist of common sets of bureaucratic bodies, which include a congress that serves the common interest independently of national governments. Subsequently, political order at a Nordic level would require an independent Nordic administrative system with some organizational capacities of its own. It would require the existence of independent administrative capacities within and around the Nordic Council of Ministers as the executive arm of the Nordic Council. The development and implementation of public policy from a 'Nordic' perspective would require the supply of such independent Nordic administrative capacities (Olesen \& Strang, 2016). Etzold (2020), however, shows that such level of administrative independence does not exist at the Nordic level despite many commonalities and the close cooperation among its countries. Lacking any supranational elements, the institutions of Nordic cooperation are in practice not sufficiently independent.

\subsection{Influence}

Political order also requires that political institutions be relatively able to influence decision-making processes within subordinate institutions of a system. More generally, the independence and integration of administra- 
tive capacities may not only influence how public policy is formulated and implemented, it may also affect the capacity to influence and challenge other institutions (Ahrne \& Brunsson, 2019). Within the EU, the European Commission has requisite capacities to influence governance processes within EU agencies as well as national agencies, making national agencies 'double hatted' serving both as national and EU-level regulatory bodies. Studies suggest that the European Commission has de facto capacities to influence everyday governing activities of domestic agencies-making them in practice partly European and partly national (Egeberg \& Trondal, 2017) as well as making them autonomous vis-à-vis their parent ministries (Bach, Ruffing, \& Yesilkagit, 2015).

However, without requisite independent administrative capacities at its disposal, Nordic cooperation is largely centered on the cooperative behavior among member-state agencies. It is fundamentally the discretionary behavior of agency personnel and sub-units among the Nordic member-states that make up the core fabric of Nordic administrative cooperation. Lægreid and Rykkja (2020) and Kjøndal (2020) substantiate that Nordic cooperation is largely centered on agency-toagency cooperation within policy sub-systems. Olesen and Strang (2016, p. 28) similarly argue that the Nordic Council of Ministers was largely established on the basis of pre-existing administrative networks among Nordic agencies. This has also been illustrated in a case study of the Norwegian Statistical Agency. Originating in 1889, Nordic statistical cooperation has largely been centered on horizontal network cooperation among national regulatory agencies with a focus on how to develop shared methodologies, statistical registers and user information. Agency directors have met regularly, followed by regular meetings among lower-ranked staff who share common portfolios. Moreover, these networks and meetings have been used to prepare meetings both in Eurostat and in the Nordic Council (Teigen \& Trondal, 2015).

As outlined below, an MLA approach is also an organizational approach to public governance. From an organizational theory point of view, the question of how administrative institutions are organized is thought to affect how they evolve and work (Egeberg \& Trondal, 2018). The horizontal specialization of administrations and their sub-units may for example affect how they influence other institutions. For example, the sector-specialization of the Secretariat of the Nordic Council of Ministers is likely to mobilize sector-specialized cooperation among Nordic ministries and agencies. This may cause the development of direct relationships between administrative units of the Nordic Council of Ministers and corresponding national agencies, thus generating sectoral ties between administrative bodies at Nordic and domestic level. Olesen and Strang (2016) show how meetings among Nordic bureaucrats contribute to developing and maintaining a 'Nordic ethos,' illustrated by the many common declarations that have been signed among Nordic countries in certain policy domains.

\subsection{Integration}

A final characteristic of political order is the extent to which they are internally integrated and able to act coherently. The question is thus how competing patterns of administrative integration and coordination and disintegration, or fragmentation and siloization, co-exist within and among institutions. Studies observe that the emergence of common political orders does not necessarily lead to the rise of coherent and integrated institutions. Instead, Orren and Skowronek (2004) suggest that different elements of administrative bodies tend to overlap, counteract, and be poorly coordinated rather than coordinated and well 'ordered.' Studies show that parallel to the vertical specialization of administrative systems, there is a push for administrative coordination and centralization within national governments, strengthening the executive branch of government (Poguntke \& Webb, 2005). This pattern is also observed within the European Commission. Contemporary studies of the European Commission reveal it has become increasingly internally coordinated-both between the different layers of the Commission administration as well as between the Commission administration and the political level (College of Commissioners and their cabinets; e.g., Kassim, Connolly, Dehousse, Rozenberg, \& Benjamballah, 2017). These observations are also reflected throughout the history of the European Commission with periods of internal integration and periods of internal disintegration. This was illustrated in the Jaques Delors Commission (1985-1994) which was characterized by presidential power and a neglect of ordinary administrative rules and routines (Christiansen, 2008, p. 63). Kassim et al. (2013) show how the European Commission president has gained more organizational capacities, notably by strengthening the Secretariat-General into a political secretariat for the President. However, Trondal (2012) also shows parallel processes of administrative siloization and turf wars between departments (Directorate-Generals) of the European Commission.

In short, political order involves continuous balancing-acts between and complex co-existences of integration and disintegration of administrative systems. However, there are no studies that have empirically mapped this dimension within the Nordic Council of Ministers, or adjacent institutions.

\section{Conceptual Added Value}

With an ambition to argue for a public administration approach to the study of political order, the conceptual dimensions outlined above may serve not only to understand elements of political order, but also to accentuate what makes a public administration approach different from its conceptual alternative-the MLG approach. In short, an MLA approach highlights analytical dimensions that remain largely untouched by MLG literature. This section operationalizes variations between the MLG 
and the MLA approaches, and also shows how these two approaches may complement each other. However, the section does not offer a thorough review of each literature, which has been provided elsewhere (e.g., Bache \& Flinders, 2004; Bauer \& Trondal, 2015; Piattoni, 2010). Three conceptual differences are discussed in the following: (i) Units of analysis; (ii) ideas on organizational differentiation; and essentially (iii) causal mechanisms.

\subsection{Units of Analysis}

The MLG approach has focused on sub-national authorities, or regions, as unit of analysis, and highlighted the complex actorhood that spans levels of authority in contemporary public governance processes (Ongaro, 2015; Marks, Hooghe, \& Schekel, 2008, p. 113; Marks, Nielsen, $\&$ Ray, 1996). This approach focuses on how the authority of regions gives them requisite capacities to by-pass national governments in their interaction with EU institutions. Due to the interconnection of political authority across levels of governance, it is argued that the distinction between domestic and international relations as well as between domestic and foreign policy administrations has become obsolete, and as a consequence regional actors tend to mobilize policy attention beyond the state (Hooghe \& Marks, 2001, p. 4). By contrast, the MLA approach focuses on the administrative structures of political order at different levels of government, notably on the mutual interaction of bureaucratic subunits across levels of governance. Empirical studies that have used the MLA approach have paid attention to the interaction of administrative sub-units across levels of governance and how such interaction influences bureaucratic autonomy, behavioral logics and administrative styles among administrative office holders (Bauer et al., 2019; Egeberg, 2006; Trondal \& Peters, 2013). Focus is thus directed towards how government administrations 'mobilize biases' in governance processes and systematically shape administrative behavior among civil servants (Schattschneider, 1975; Simon, 1965). The MLA approach assumes that how bureaucracies and their sub-units are organized at all levels of government is likely to systematically shape the administrative behavior evoked by bureaucratic staff, and ultimately influence multilevel administrative governance processes.

\subsection{Organizational Differentiation}

Although the MLG approach successfully challenged the unitary conception of the nation-state, it simultaneously treated its unit of analysis-regions-as 'black boxes.' In short, the operationalization of regional authority did not include the organizational structuring of subnational institutions (Marks et al., 2008, p. 115). As a consequence, Ongaro (2015) criticized the MLG literature for being a loose umbrella concept rather than a clearcut theory. To illustrate, Marks et al. (2008) carefully measured local authority by the use of nine dimensions. Along all dimensions, regions were treated as coherent wholes. Neither of these dimensions suggested how administrative characteristics of sub-national institutions should be conceptualized or applied to a causal model. As a consequence of an absence of an organizational (bureaucratic) dimension, the MLG approach focused on "the allocation of authority across general-purpose jurisdictions" (Marks et al., 2008, p. 111). One explanation for this is the rationalist ontology of MLG which treats administrative institutions as epiphenomena to the interaction of regions (see Section 5.3).

The MLA approach, by contrast, treats the unit of analysis as internally differentiated. Echoing the ideas of institutional polycentrism that studied systems of interconnected sub-units (Ostrom, 2009), the MLA approach assumes that politico-administrative institutions are potentially internally differentiated and that patterns of differentiation systematically influence and bias multilevel administrative governance processes. Viewing political orders as organizationally differentiated moreover implies institutional differentiation and separation of powers being conceptually and causally important (Olsen, 2016, p. 8; see next paragraph). Egeberg and Trondal (2018) suggest how organizational variables can be applied to unpack organizational differentiationssuch as organizational capacity (high/low), organizational departmentalization (horizontal/vertical), organizational association (primary/secondary), geographical locus (integrated/disintegrated), organizational demography (e.g., educational background of staff), and organizational coupling (tight/loose).

Organizational differentiation might take the form of internal and/or external differentiation. In the con-

Table 1. A conceptual comparison.

\begin{tabular}{|c|c|c|}
\hline & Multilevel governance & Multilevel administration \\
\hline Units of analysis & $\begin{array}{l}\text { Political arenas (e.g., subnational } \\
\text { authorities, regions) }\end{array}$ & $\begin{array}{l}\text { Administrative institutions (public sector organizations } \\
\text { and their sub-components) }\end{array}$ \\
\hline $\begin{array}{l}\text { Organizational } \\
\text { differentiation }\end{array}$ & $\begin{array}{l}\text { No differentiation (regions treated } \\
\text { as black boxes) }\end{array}$ & $\begin{array}{l}\text { Degrees of differentiation (administrative systems are } \\
\text { organizationally specialized systems) }\end{array}$ \\
\hline Causal mechanisms & The supply of (regional) authority & The supply of organizational routines \\
\hline
\end{tabular}

Source: Based on Trondal and Bauer (2017). 
text of Nordic cooperation, of particular relevance are secondary structures established outside and between primary structures that serve to differentiate the system. The primary organizational affiliation of decisionmakers is the unit to which $s /$ he is likely to dedicate most attention, time and resources. Examples are a ministerial department or a regulatory agency. Committees, collegial bodies and networks, on the other hand, constitute secondary structures, meaning that participants are expected to be part-timers, having their primary affiliation somewhere else, e.g., in a department or agency. Secondary structures-such as administrative networks of regulatory authorities-organize transactions by bringing together part-time participants in mutual exchange of information and expertise (Wood, 2019). Studies show that such bodies facilitate interaction, coordination and trust among primary structures (e.g., Billis \& Rochester, 2020; Klijn \& Koppenjan, 2012; Lægreid, Randma-Liiv, Rykkja, \& Sarapuu, 2016). For example, central governments that complement hierarchies with horizontal devices (e.g., interdepartmental committees) seem to be somewhat more coordinated than those relying entirely on hierarchies (Wegrich \& Stimac, 2014).

\subsection{Causal Mechanisms}

Finally, the MLG and MLA approaches diverge on core ontological ideas of causality of public governance. Although criticized for being a theoretically descriptive concept (e.g., Ongaro, 2015), the essential explanatory component of the MLG approach is actor-centered. Moreover, to the extent that institutional variables are included in the equation, they are largely applied as aggregative items (Marks et al., 1996, p. 170) and thus similar to a thin 'exchange based' idea of institutions and human choice (March \& Olsen, 1995). According to an exchange-based theory of politics, March and Olsen $(1995$, p. 7$)$ argue that "politics can be seen as aggregating individual preferences into collective action by procedures of rational bargaining, negotiation, coalition formation, and exchange." Institutional variables thus do not figure as independent variables, but largely as intervening variables that constrain human choices and policy processes. Based on a rationalist ontology, the MLG approach has successfully studied the role of subnational authority as a local push-factor for MLG (Marks et al., 2008).

The MLA approach, by contrast, argues that institutions should be treated as independent variables in the analytical model. The MLA approach thus rests on an organizational approach. An organizational approach is grounded on the assumption that organizational characteristics may explain both how organizations act as well as how they change. An organizational approach in this study emphasizes how decision processes and human behavior respond to a set of fairly stable organizational routines (Cyert \& March, 1963). Essentially, stable premises for behavioral choices are past experiences encoded in rules and expressed in the organizational structure of a government apparatus (Frederickson, Smith, Larimer, \& Licari, 2012; Olsen, 2017; Waldo, 1952). Organizational characteristics of the governmental apparatus systematically enable and constrain public governance processes, making some policy choices more likely than others. A theory of organization is thus also a theory of politics (Waldo, 1952). Organizational factors focus and mobilize attention and action capacity around certain problems and solutions while ignoring others, focus attention along particular lines of conflict and cooperation, and so on (Simon, 1983, p. 21). An organizational approach posits that organizational factors are not merely an expression of symbol politics (Feldman \& March, 1981; Meyer \& Rowan, 1977), but create systematic biases in human behavior and collective decision processes by directing and nudging individual and collective choices towards certain problems and solutions, thereby making certain outcomes more plausible than others (Egeberg \& Trondal, 2020; Fligstein, 2001; Gulick, 1937; Hammond, 1986; Schattschneider, 1975; Thaler \& Sunstein, 2009).

Contemporary studies in organization theory focus particularly on the explanatory role of organizational structure (Egeberg, 2012; Egeberg \& Trondal, 2018). An organizational structure is a normative structure, it is a decided order, composed of rules and roles specifying who is expected to do what, when and how (Ahrne \& Brunsson, 2019; Egeberg \& Trondal, 2018; Scott \& Davis, 2016). It suggests how roles, power and responsibilities are distributed, controlled and coordinated. It shapes behavior by providing individuals with "a systematic and predictable selection of problems, solutions and choice opportunities" (March \& Olsen, 1976, p. 13). While organizational structure does not necessarily predict or determine actual decision-making behavior, it does make some choices become more likely than others (e.g., Egeberg \& Trondal, 2018). As such, organization theory builds on decision theory, with its focus on explaining decision-making behavior (Simon, 1965). This entails that organizational factors do not impact directly on society; rather, they have an indirect effect by influencing the policy process and the decisions made within and outside organizations (Ahrne \& Brunsson, 2019). Bounded rationality (Simon, 1965) is one of three key mechanisms that connect role expectations to behavior; the organizational structure helps simplify actors' cognitive worlds by directing attention towards a selection of possible problems and solutions, and ways to connect them. This concept holds that decision-makers operate under three restrictions disregarded by the consequentialist theology of economic man limited information with regards to possible solutions and alternatives; limited cognitive capacity to evaluate and process information; and limited time to make decisions (March, 2011). Consequently, actors opt for a selection of satisfactory alternatives instead of optimal ones and often turn to their immediate environments and avail- 
able knowledge to find proper choices (Simon, 1965). The second mechanism - the logic of appropriatenessviews human action as driven by internalized perceptions of what is deemed appropriate (March \& Olsen, 1989). Finally, actors may find that rule and role compliance is in accordance with their self-interests and utility functions. Organizations are thus incentive systems that administer rewards and punishments (e.g., Ostrom, Ostrom, Aligica, \& Sabetti, 2015; Simon, 1983).

In this regard, the MLA approach builds on an organizational approach of public governance (ArellanoGault, Demortain, Rouillard, \& Thoenig, 2013; Egeberg \& Trondal, 2018). One such variable is the organization of administrative capacities supplied at each level of government. The MLA approach suggests that how such organizational capacities are distributed in sub-unit levels at each level of government is likely to influence human choices and policy processes. Moreover, organizations at different levels that are structured by competing principles may provide multiple and competing choicearchitectures for decision-makers, making them aware of multiple preferences, concerns and considerations during the decision-making cycle. Moreover, organizational capacities provide government institutions with leverage to act independently, to enable them some degree of internal integration, and to make them influential towards external institutions (see Section 4.2).

\section{Conclusions}

This article has drawn attention to a public administration approach to the study of political order. Moreover, the study suggests how this approach adds value by outlining an organization theory of public governance. In sum, the article suggests that a public administration approach is a necessary, yet often neglected, element in a general theory of political order. Focusing on the administrative dimension of politics, this conceptual framework is also a (partial) theory of political organization.

The empirical laboratories that are available to social science are likely to bias the theoretical lessons that are drawn. As the discipline of public administration has been largely locked in national laboratories, the theoretical apparatus available to understand the administrative dimension of Nordic cooperation in particular, and European (multilevel) integration in general, is limited. As a consequence, the sub-discipline of public administration in political science has paid scarce attention to how administrative systems are essential ingredients to (Nordic) political order. This article aims to capture the administrative dimension of (Nordic) political order along three conceptual dimensions: institutional independence, integration, and influence. These dimensions serve to accentuate what makes a public administration lens valuable as well as the organizational dimension of such processes important. Due to organizational differentiation of government apparatuses (cf. Section 5.2), administrative cooperation among Nordic ministries and agencies are likely to follow sectoral lines (Kjøndal, 2020; Teigen \& Trondal, 2015).

A public administration approach is more generally helpful for studying the consolidation of embryonic political orders. According to March and Olsen (1995), organizations and organized systems are merely temporary systems of rules and roles, and according to Rokkan (1999) they are provisional resolutions of societal conflicts. A public administration approach to the study of political order helps to capture how emergent political orders that span multiple tiers of authoritative decision-making are dependent on certain administrative resources. This article, however, suggests that Nordic-level institutions are less likely to act relatively integrated and independently of member-state governments and less likely to wield significant influence on public governance processes within member-state institutions. In the case of Nordic cooperation, most primary administrative capacities are located within national ministries and agencies, and relatively few at the 'Nordic level.' Member-state administrations are subsequently likely to primarily influence policy agendas and policy implementation.

\section{Acknowledgments}

The author would like to acknowledge helpful and constructive comments from anonymous reviewers.

\section{Conflict of Interests}

The author declares no conflict of interests.

\section{References}

Ahrne, G., \& Brunsson, N. (Eds.). (2019). Organization outside organizations: The abundance of partial organizations in social life. Cambridge: Cambridge University Press.

Ansell, C., \& Di Palma, G. (2004). Restructuring territoriality. Cambridge: Cambridge University Press.

Ansell, C., Trondal, J., \& Ogard, M. (Eds.). (2016). Governance in turbulent times. Oxford: Oxford University Press.

Arellano-Gault, D., Demortain, D., Rouillard, C., \& Thoenig, J.-C. (2013). Bringing public organizations and organizing back in. Organization Studies, 34(2), 145-67.

Bach, T., Ruffing, E., \& Yesilkagit, K. (2015). The differential empowering effects of Europeanization on the autonomy of national agencies. Governance, 28(3), 285-304.

Bache, I., \& Flinders, M. (2004). Multi-level governance. Oxford: Oxford University Press.

Barnett, M., \& Finnemore, M. (2004). Rules for the world: International organizations in world politics. Ithaca, NY: Cornell University Press.

Bartolini, S. (2005). Re-structuring Europe. Oxford: Oxford University Press. 
Bauer, M. W., Beyerlein, L., Ege, J., Knill, C., \& Trondal, J. (2019). Perspectives on international public administration research: A rejoiner to Johan Christensen and Kutsal Yesilkagit (ARENA Working Paper 1/2019). Oslo: University of Oslo.

Bauer, M. W., \& Trondal, J. (2015). The administrative system of the European Union. In M. W. Bauer \& J. Trondal (Eds.), The Palgrave handbook of the European administrative system (pp. 1-30). Houndmills: Palgrave Macmillan.

Benz, A. (2015). European public administration as a multilevel system administration: A conceptual framework. In M. W. Bauer \& J. Trondal (Eds.), The Palgrave handbook on the European administrative system (pp. 31-47). Houndmills: Palgrave Macmillan.

Bickerton, C. J. (2012). European integration. Oxford: Oxford University Press.

Biermann, F., \& Siebenhüner, B. (Eds.). (2009). Managers of global change. Cambridge, MA: MIT Press.

Billis, D., \& Rochester, C. (Eds.). (2020). Handbook on hybrid organisations. Cheltenham: Edward Elgar.

Bobrow, D. B., Eulau, H., Landau, M., Jones, C. O., \& Axelrod, R. (1977). The place of policy analysis in political science: Five perspectives. American Journal of Political Science, 21(2), 415-433.

Boin, A., \& Lodge, M. (2016). Designing resilient institutions for transboundary crisis management: A time for public administration. Public Administration, 94(2), 289-298.

Bulmer, S. (2008). Building a multi-level polity in Europe. In U. Sverdrup \& J. Trondal (Eds.), The organizational dimension of politics (pp. 170-185). Bergen: Fagbokforlaget.

Cassese, S. (1987). Divided powers: European administration and national bureaucracies. In D. Berlin, S. Pag, \& C. Bourtembourg (Eds.), The European administration (pp. 2-18). Maastricht: EIPA.

Checkel, J. T. (2005). International institutions and socialization in Europe. International Organization, 59(4), 801-826.

Christensen, T., \& Lægreid, P. (2007). Transcending new public management. Aldershot: Ashgate.

Christensen, T., \& Lægreid, P. (2011). Beyond NPM? Some development features. In T. Christensen \& P. Lægreid (Eds.), The Ashgate research companion to new public management (pp. 391-404). Aldershot: Ashgate.

Christiansen, T. (2008). The institutional politics of the European Union. (Unpublished doctoral dissertation). University of Maastricht, Maastricht, The Netherlands.

Curtin, D., \& Egeberg, M. (2008). Tradition and innovation: Europe's accumulated executive order. West European Politics, 31(4), 639-661.

Cyert, R. M., \& March, J. G. (1963). A behavioral theory of the firm. Englewood Cliffs, NJ: Prentice Hall.

Danielsen, O. A., \& Yesilkagit, K. (2014). The effects of European regulatory networks on the bureaucratic au- tonomy of national regulatory authorities. Public Organization Review, 14, 353-371.

Egeberg, M. (Ed.). (2006). Multilevel union administration. Houndmills: Palgrave Macmillan.

Egeberg, M. (2010). L'administration de I'Union Europeenne: Niveaux multiples et construction d'un centre [EU administration: Centre formation and multilevelnes]. Revue Francaise d'Administration Publique, 133, 17-26.

Egeberg, M. (2012). How bureaucratic structure matters: An organizational perspective. In B. G. Peters \& J. Pierre (Eds.), The Sage handbook of public administration (pp. 157-168). London: SAGE.

Egeberg, M., \& Trondal, J. (2009). National agencies in the European administrative space: Government driven, Commission driven, or networked? Public Administration, 87(4), 779-790.

Egeberg, M., \& Trondal, J. (2016). Why strong coordination at one level of government is incompatible with strong coordination across levels (and how to live with it): The case of the European Union. Public Administration, 94(3), 579-592.

Egeberg, M., \& Trondal, J. (2017). Researching European Union agencies: What have we learned (and where to go from here). Journal of Common Market Studies, 55(4), 675-690.

Egeberg, M., \& Trondal, J. (2018). An organizational approach to public governance. Oxford: Oxford University Press.

Egeberg, M., \& Trondal, J. (2020). The organizational basis for public governance. The Oxford Research Encyclopedia of Politics, 2020, 1-28. https://doi.org/ 10.1093/acrefore/9780190228637.013.1491

Elster, J. (2007). Explaining social behavior. Cambridge: Cambridge University Press.

Emery, Y., \& Giauque, D. (2014). The hybrid universe of public administration in the 21st century. International Review of Administrative Sciences, 80(1), 23-32.

Etzold, T. (2020). The Nordic council of ministers: Aspirations for more political relevance. Politics and Governance, 8(4), 11-20.

Feldman, M. S., \& March, J. G. (1981). Information in organizations as signal and symbol. Administrative Science Quarterly, 26(2), 171-186.

Fligstein, N. (2001). Organizations: Theoretical debates and the scope of organizational theory (Working paper). Berkeley, CA: UC Berkeley.

Frederickson, H. G., Smith, K. B., Larimer, C. W., \& Licari, M. J. (2012). The public administration theory primer. Boulder, CO: Westview Press.

Fukuyama, F. (2013). What is governance? Governance, 26(3), 347-368.

Fukuyama, F. (2016). Macro theory and the study of political development. Scandinavian Political Studies, 39(3), 207-225.

Gulick, L. (1937). Notes on the theory of organizations: With special references to government in the United 
States. In L. Gulick \& L. F. Urwick (Eds.), Papers on the science of administration (pp. 1-46). New York, NY: Institute of Public Administration, Columbia University.

Haas, E. B. (1958). The uniting of Europe. Notre Dame, IN: Notre Dame Press.

Hammond, T. H. (1986). Agenda control, organizational structure, and bureaucratic politics. American Journal of Political Science, 30(1), 379-420.

Hofmann, H. C. H., \& Turk, A. H. (Eds.). (2006). EU administrative governance. Cheltenham: Edward Elgar.

Hooghe, L., \& Marks, G. (2001). Multilevel governance and European integration. New York, NY: Rowman \& Littlefield Publishers.

Huntington, S. P. (1968). Political order in changing societies. New Haven, CT: Yale University Press.

Kassim, H., Connolly, S., Dehousse, R., Rozenberg, O., \& Benjamballah, S. (2017). Managing the house: The presidency, agenda control and policy activism in the European Commission. Journal of European Public Policy, 24(5), 653-674.

Kassim, H., Peterson, J., Bauer, M. W., Connolly, S., Dehousse, R., Hooghe, L., \& Thompson, A. (2013). The European Commission of the twenty-first century. Oxford: Oxford University Press.

Keohane, R. O., Macedo, S., \& Moravcsik, A. (2009). Democracy-enhancing multilateralism. International Organization, 63(1), 1-31.

Klijn, E. H., \& Koppenjan, J. F. M. (2012). Governance network theory: Past, present and future. Policy and Politics, 40(4), 187-206.

Kjøndal, K. (2020). Nordic cooperation in the nuclear safety sector: High, low, or differentiated integration? Politics and Governance, 8(4), 33-43.

Knill, C. (2001). The Europeanisation of national administrations. Cambridge: Cambridge University Press.

Lægreid, P., Randma-Liiv, T., Rykkja, L. H., \& Sarapuu, K. (2016). Coordination challenges and administrative reforms. In G. Hammerschmid, S. Van de Walle, R. Andrews, \& P. Bezes (Eds.), Public administration reforms in Europe (pp. 244-258). Cheltenham: Edward Elgar.

Lægreid, P., \& Rykkja, L. H. (2020). Nordic administrative collaboration: Scope, predictors and effects on policy design and administrative reform measures. Politics and Governance, 8(4), 21-32.

March, J. G. (1999). A learning perspective on the network dynamics of institutional integration. In M. Egeberg \& P. Lægreid (Eds.). Organizing political institutions: Essays for Johan P. Olsen (pp. 129-158). Oslo: Scandinavian University Press.

March, J. G. (2011). A Scholar's Quest. Journal of Management Inquiry, 20(4), 355-357. https://doi.org/ $10.1177 / 1056492611432803$

March, J. G., \& Olsen, J. P. (1976). Ambiguity and choice in organizations. Bergen: Scandinavian University Press.

March, J. G., \& Olsen, J. P. (1989). Rediscovering institutions. New York, NY: The Free Press.

March, J. G., \& Olsen, J. P. (1995). Democratic governance. New York, NY: The Free Press.
Marks, G. (1993). Structural policy and multilevel governance in the EC. InA. W. Cafruny \& G. G. Rosenthal (Eds.), The state of the European community: The Maastricht debates and beyond (pp. 391-410). Boulder, CO: Lynne Rienner.

Marks, G., Hooghe, L., \& Schekel, A. H. (2008). Measuring regional authority. Regional and Federal Studies 18(2/3), 111-121.

Marks, G., Nielsen, F., \& Ray, L. (1996). Competencies, cracks, and conflicts: Regional mobilization in the European Union. Comparative Political Studies, 29(2), 164-192.

Matthews, F. (2012). Governance and state capacity. In D. Levi-Faur (Ed.), The Oxford handbook of governance (pp. 281-293). Oxford: Oxford University Press.

Meyer, J. W., \& Rowan, B. (1977). Institutionalized organizations: Formal structure as myth and ceremony. American Journal of Sociology, 83(2), 340-363.

Meyer-Sahling, J. H., \& Yesilkagit, K. (2011). Differential legacy effects: Three propositions on the impact of administrative traditions on public management reform in Europe east and west. Journal of European Public Policy, 18(2), 311-322.

Moravcsik, A. (1998). The choice for Europe. Ithaca, NY: Cornell University Press.

Niemann, A. (2006). Explaining decisions in the European Union. Cambridge: Cambridge University Press.

Olesen, T. B., \& Strang, J. (2016). European challenge to Nordic institutional cooperation: Past, present, future. In J. Strang (Ed.), Nordic cooperation (pp. 27-47). London: Routledge.

Olsen, J. P. (2003). Towards a European administrative space? Journal of European Public Policy, 10(4), 506-531.

Olsen, J. P. (2007). Europe in search of political order. Oxford: Oxford University Press.

Olsen, J. P. (2016). Democratic accountability and the terms of political order. European Political Science Review, 9(4), 519-537.

Olsen, J. P. (2017). Democratic accountability, political order, and change. Oxford: Oxford University Press.

Ongaro, E. (2015). Multi-level governance: The missing linkages. In E. Ongaro (Ed.), Multi-level governance: The missing linkages (pp. 1-20). Bingley: Emerald.

Orren, K., \& Skowronek, S. (2004). The search for American political development. Cambridge: Cambridge University Press.

Ostrom, E. (2009). A general theory framework for analyzing sustainability of social-ecological systems. Science, 325(5939), 419-422.

Ostrom, E., Ostrom, V., Aligica, P. D., \& Sabetti, P. (2015). Choice, rules and collective action. Colchester: ECPR Press.

Padgett, J. F., \& Powell, W. W. (2012). The emergence of organizations and markets. Princeton, NJ: Princeton University Press.

Pag, S. (1987). The relations between the Commission and national bureaucracies. In S. Cassese (Ed.), The 
European administration (pp. 443-497). Maastricht: IIAS and EIPA.

Painter, M., \& Peters, B. G. (Eds.). (2010). Tradition and public administration. Houndmills: Palgrave Macmillan.

Pepinsky, T. B., \& Walter, S. (2019). Introduction to the debate section: Understanding contemporary challenges to the global order. Journal of European Public Policy, 27(8), 1074-1076.

Piattoni, S. (2010). The theory of multilevel governance. Oxford: Oxford University Press.

Poguntke, T., \& Webb, P. (Eds.). (2005). The presidentialization of politics. Oxford: Oxford University Press.

Raadschelders, J. C. N. (2011). Public administration. Oxford: Oxford University Press.

Riddervold, M., Trondal, J., \& Newsome, A. (Eds.). (2020). The Palgrave handbook of EU crises. Houndmills: Palgrave Macmillan.

Rittberger, B., \& Wonka, A. (2011). Introduction: Agency governance in the European Union. Journal of European Public Policy, 18(6), 780-789.

Rokkan, S. (1999). State formation, nation building, and mass politics in Europe. Oxford: Oxford University Press.

Rosenau, J. N. (1966). Pre-theories and theories of foreign policy. In R. B. Farrell (Ed.), Approaches to comparative and international politics (pp. 19-39). Evanston, IL: Northwestern University Press.

Rothstein, B. (2012). Good governance. In D. L. Faur (Ed.), The Oxford handbook on governance (pp. 143-154). Oxford: Oxford University Press.

Saint-Simon, H. (1964). Social organization, the science of man and other writings. New York, NY: Harper Torchbooks.

Schattschneider, E. E. (1975). The semisovereign people. Fort Worth, TX: Harcourt Brace Jovanovich College Publishers.

Scott, W. R., \& Davis, G. F. (2016). Organizations and organizing. London: Routledge.

Simon, H. A. (1965). Administrative behavior. New York, NY: The Free Press.

Simon, H. A. (1983). Reason in human affairs. Stanford, CA: Stanford University Press.

Stinchcombe, A. L. (1987). Constructing social theories. Chicago, IL: The University of Chicago Press.

Tamuz, M., \& Lewis, E. T. (2008). Facing the threat of disaster: Decision making when the stakes are high. In G. P. Hodgkinson \& W. H. Starbuck (Eds.), The Oxford handbook of organizational decision making (pp. 155-173). Oxford: Oxford University Press.
Teigen, D. O., \& Trondal, J. (2015). Fler-nivåadministrasjon på statistikkområdet [Multilevel administration in the field of statistics]. Nordisk Administrativt Tidsskrift, 92(3), 24-41.

Thaler, R. H., \& Sunstein, C. R. (2009). Nudge: Improving decisions about health, wealth and happiness. London: Penguin Books.

Trondal, J. (2007). The public administration turn in integration research. Journal of European Public Policy, 14(6), 960-972.

Trondal, J. (2010). An emergent European executive order. Oxford: Oxford University Press.

Trondal, J. (2012). On bureaucratic centre formation in government institutions: Lessons from the European Commission. International Review of Administrative Sciences, 78(3), 425-446.

Trondal, J. (2014). Agencification. Public Administration Review, 74(4), 545-549.

Trondal, J. (2016). Advances to the study of international public administration. Journal of European Public Policy, 23(7), 1097-1108.

Trondal, J. (2017). The rise of independent international administration: The case of the International Atomic Energy Agency (IAEA). In J. Trondal (Ed.), The rise of common political order (pp. 49-68). Cheltenham: Edward Elgar.

Trondal, J., \& Bauer, M. W. (2017). Conceptualizing the European multilevel administrative order: Capturing variation in the European administrative system. European Political Science Review, 9(1), 73-94.

Trondal, J., Marcussen, M., Larsson, T., \& Veggeland, F. (2010). Unpacking international organisations: The dynamics of compound bureaucracies. Manchester: Manchester University Press.

Trondal, J., \& Peters, B. G. (2013). The rise of European administrative space: Lessons learned. Journal of European Public Policy, 20(2), 295-307.

Waldo, D. (1952). Development of theory of democratic administration. American Political Science Review, 46(1), 81-103.

Waldo, D. (1992). The enterprise of public administration. Novato, CA: Chandler \& Sharp Publishers.

Wegrich, K., \& Stimac, V. (2014). Coordination capacity. In M. Lodge \& K. Wegrich (Eds.) The problem-solving capacity of the modern state (pp. 41-62). Oxford: Oxford University Press.

Wilson, J. Q. (1989). Bureaucracy. New York, NY: Basic Books.

Wood, M. (2019). Hyper-active governance. Cambridge: Cambridge University Press.

\section{About the Author}

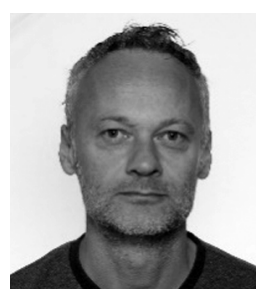

Jarle Trondal is Professor of Political Science at the University of Agder and at the University of OsloARENA Centre for European Studies. His main fields of research are public administration, governance, European integration, organizational studies and international organizations. 